\title{
The Effectiveness of Lavender Aromatherapy In Changing Blood Pressure In Middle Age With Primary Hypertension In Mojokerto Regency of East Java Province
}

\author{
Hartin Suidah \\ Dian Husada Nursing Academy Of Mojokerto, East Java \\ Ninik Murtiyani \\ Dian Husada Nursing Academy Of Mojokerto, East Java \\ Linda Presti Fibriana \\ Dian Husada Nursing Academy Of Mojokerto, East Java \\ Nuris Kushayati \\ Dian Husada Nursing Academy Of Mojokerto, East Java \\ Yufi Aris Lestari \\ High School Of Health Sciences Dian Husada Of Mojokerto, East Java
}

\begin{abstract}
Background: In 2010, hypertension case becomes one out of 10 most prevalent diseases in Indonesia with prevalence of $8.24 \%: 3.49 \%$ in male and $4.75 \%$ in female [8]. The objective of research was to analyze the effectiveness of lavender aromatherapy in changing blood pressure in middle age with primary hypertension. Method: This research employed Quasi Experiment method with control group time series design. The sample of research consisted of 32 respondents taken using probability sampling with simple random technique. Data analysis was conducted based on data tabulation with paired T-test with $\alpha=0.05$. Result: After lavender administration for 7 days, on average, the respondents' blood pressure decreases from $1^{\text {st }}$ degree hypertension, $2^{\text {nd }}$ degree hypertension, and $3^{\text {rd }}$ degree hypertension to normal pressure, high normal pressure. The result of paired $T$ test obtained significance level $p=0.008$ or less than $\alpha=0.05$. Conclusion: Lavender aromatherapy effectively changed the blood pressure in middle age with primary hypertension.
\end{abstract}

Keywords: Lavender Aromatherapy, Primary Hypertension, Blood Pressure, Middle Age

\section{INTRODUCTION}

The improvement of population health and wellbeing degree will improve Life Expectancy in Indonesia. World Health Organization (WHO) reports that in Life Expectation is 55.7 years in 1980, increasing from 59.5 years in 1990, and expectedly becomes 71.7 years in 2020 [8]. Middle age is considered as the age period between 40 and 60 years. The period is characterized with physical and mental changes. An individual aged 40 years has experienced degenerative process, leading to decreased cell number in the body and decreased organ function that will affect body metabolism system and can result in such diseases as hypertension. Hypertension has been the $3^{\text {rd }}$ number-health problem in the word; it is characterized with the increased hypertension incidence over years. This condition should be anticipated as hypertension is one of risk factor that can increase sickness and death rates, 
Suidah, H., Murtiyani, N., Fibriana, L. P., Kushayati, N., \& Lestari, Y. A. (2018). The Effectiveness of Lavender Aromatherapy In Changing Blood Pressure In Middle Age With Primary Hypertension In Mojokerto Regency Of East Java Province. Advances in Social Sciences Research Journal, 5(3) $19-26$

particularly in both developed and developing countries among not only elderly but also middle age. Undertaking pharmacological therapy, hypertension patients should consume drug routinely leading to boredom, so that they comply with drug consumption less adequately and it becomes the primary reason of pharmacological therapy failure. In addition, side effect of pharmacological therapy includes cough, insomnia, hypotension, sexual dysfunction, fatigue, and renal dysfunction in continuous consumption, thereby influencing the hypertension patients to prefer stopping pharmacological therapy [5]. One of non-pharmacological therapy is aromatherapy constituting one of health service forms coping with a variety of diseases with comfortable treatment technique and resulting in relaxation.

About $30 \%$ of American populations ( \pm 50 millions people) develop high blood pressure ( $\geq$ $140 / 90 \mathrm{mmHg}$ ), with substantial annual health cost percentage. National Health and Nutrition Examination Survey (NHNES) shows that hypertension incidence was about $39-51 \%$ during 2010-2012 in USA, meaning that there are 58-65 people developing hypertension; it increases by 15 millions compared with the data of NHNES III. Data of ACCF/AHA 2011 Expert Consensus Document on Hypertension in the Elderly suggests that $35 \%$ of patients with hypertension are 40-49 years old and 10\% are 50-59 years old. WHO records that there are at least 839 millions hypertension cases, expectedly increasing to 1.15 billions in 2025 or about $29 \%$ of total world population, with female patients being larger (30\%) in number than the male ones (29\%). About $80 \%$ of hypertension case increase occurs particularly in developing countries, including Indonesia [13]. The result of Household Health Survey (Survey Kesehatan Rumah Tangga, thereafter called SKRT) in 2000 suggests that it reached $21 \%$ in 2000 , increasing to $26.4 \%$ and $27.5 \%$ in 2001 and 2004, expectedly increasing to $37 \%$ in 2015 and to $42 \%$ in 2025 . Considering the data of ten most prevalent diseases in Indonesia in 2010, the prevalence of hypertension case is $8.24 \%$ : $3.49 \%$ in male and $4.75 \%$ in female [7]. The prevalence of hypertension in Indonesia is $31.7 \%$ of population at 18-year and above age. Out of this figure, $60 \%$ of hypertension patients end up with stroke. Meanwhile the rest ends up with cardiac disease, renal dysfunction, and blindness. East Java has hypertension prevalence of 26/2\%, occupying the $12^{\text {th }}$ ranking following Central Java [15]. Data of Mojokerto City's Health Service shows that $22 \%$ of populations develop hypertension [4]. Data of Puskesmas Trowulan, Mojokerto Regency, shows that hypertension prevalence is $10.5 \%$, occupying the $5^{\text {th }}$ ranking following URI (18.8\%), pulmonary TB BTA + (15.1\%), Diabetes Mellitus (12.3\%), Gastritis (11.7\%). Ponkesdes of Jambuwok Village of Trowulan Sub District of Mojokerto Regency has hypertension prevalence of $21 \%$. The result of interview with 10 respondents constituting the people of Lengkong Hamlet, Jambuwok Village, Trowulan Sub District of Mojokerto Regency shows that 4 respondents with hypertension symptom prefer sleeping and taking a rest to deal with the symptom of hypertension, one of which has ever consumed cucumber and 5 others consumed pharmacological drugs and showed boredom addiction with those blood pressure decreasing drugs and feared of their side effect.

The high prevalence of hypertensive patients is a problem affecting the community health degree. Changing lifestyle, age, race, family history, sex, obesity, inadequate sport, smoking, stress and attitude trigger the hypertension incidence [19]. Its symptom includes: headache, sharp chest pain, dizziness, sleep disorder, breath shortness during doing some activities, heart pulsation, nosebleed, numbness or pins and needles, restlessness and bad temper, excessive sweat, muscle cramp, weakness, swelling under eyes in the morning [17]. Hypertension is closely related to cardiovascular disease incidence risk so that the higher blood pressure, the higher is the likelihood of renal disease, stroke, heart attack and heart failure incidence [9]. 
Hypertension incidence rate increases over years so that blood pressure control can be done with management. There are two methods of treating hypertension: pharmacological and nonpharmacological, complementary therapy that can decrease blood pressure as well, one of which is aromatherapy [6]. Aromatherapy can help heal hypertensive patients in relieving them from stress and other stress-related symptoms such as anxiety, insomnia, and depression. Inhaling aromatherapy oil is considered as the most direct and quickest healing method. It is because the molecules of volatile essential oil react directly with olfactory organ and perceived directly by brain. Essential oils such as lavender, ylang-ylang, helichrysum, marjoram, and lemon are usually used to decrease high blood pressure. Lavender is found effectively dealing with anxiety, stress, and depression as a strong sedative, recovering muscle fatigue, and helping blood circulation. Lavender largely contains ester (26\%-52\%) that can exert sedating effect and direct effect on nervous system [20]. Lavender aromatherapy is one of complementary healthcare service forms coping with hypertension disease, thereby becoming an alternative treatment.

\section{OBJECTIVE}

The objective of research is to analyze the effectiveness of lavender aromatherapy on changing blood pressure in middle age with primary hypertension.

\section{METHOD}

This research employed Quasi Experiment method with Control Group Time Series Design. This design employed two groups: treatment and control. Before conducting pretest treatment, blood pressure measurement would be conducted on the two groups; afterwards, intervention was administered to treatment group by administering lavender aromatherapy for \pm 10 minutes within 7 successive administration days (days-1, $-2,-3,-4,-5,-6$, and -7) and after the treatment (posttest), blood pressure measurement was conducted again on the two groups. The target population of research included all middle age respondents with primary hypertension in Lengkong Hamlet, Jambuwok Village of Trowulan Sub District of Mojokerto Regency, consisting of 42 respondents. Meanwhile, the population reached in this research included those developing primary hypertension in Lengkong Hamlet, Jambuwok Village of Trowulan Sub District of Mojokerto Regency available to be respondents. Having been adjusted with the research criteria, the reached population was obtained, consisting of 35 hypertensive respondents. The sample was taken using probability sampling with simple random sampling technique. Meanwhile, the sampling between treatment and control groups was conducted randomly.

\section{RESULT}

Table 4.1. Classification of Blood Pressure Before Lavender Aromatherapy Administration

\begin{tabular}{|c|c|c|c|c|c|c|c|c|c|}
\hline \multirow[t]{2}{*}{ No } & \multirow{2}{*}{$\begin{array}{c}\text { Blood Pressure } \\
\text { Classification }\end{array}$} & \multicolumn{4}{|c|}{ Treatment } & \multicolumn{2}{|c|}{ Control } & \multicolumn{2}{|c|}{ Total } \\
\hline & & & $\mathrm{F}$ & & $\%$ & $\mathrm{~F}$ & $\%$ & $\mathrm{~F}$ & $\%$ \\
\hline 1 & Optimal Blood Pressure & - & 0 & - & 0 & 0 & 0 & 0 & 0 \\
\hline 2 & Normal Blood Pressure & - & 0 & - & 0 & 0 & - & 0 & - \\
\hline 3 & $\begin{array}{l}\text { High Normal Blood } \\
\text { Pressure }\end{array}$ & - & 0 & - & 0 & 0 & - & 0 & - \\
\hline 4 & $1^{\text {st-degree Hypertension }}$ & - & 5 & & 31.25 & 7 & 43.75 & 12 & 37.5 \\
\hline 5 & $2^{\text {nd-degree Hypertension }}$ & - & 10 & & 62.5 & 8 & 50 & 18 & 56.25 \\
\hline 6 & $3^{\text {rd-degree Hypertension }}$ & - & 1 & & 6.25 & 1 & 6.25 & 2 & 6.25 \\
\hline 7 & $\begin{array}{l}\text { Isolated Systolic } \\
\text { Hypertension }\end{array}$ & - & 0 & - & 0 & 0 & $-\quad 0$ & 0 & $-\quad 0$ \\
\hline Total & & - & 16 & & 100 & 16 & 100 & 32 & 100 \\
\hline
\end{tabular}

Table 4.1 shows the classification of blood pressure developed by respondents. Most respondents developed hypertension in treatment group including 10 respondents (62.5\%) 
with $2^{\text {nd }}$-degree hypertension and 1 (6.25\%) with $3^{\text {rd }}$-degree hypertension. Meanwhile, a half of respondents in control group developed hypertension, including 8 respondents (50\%) with $2^{\text {nd }}$-degree hypertension and $1(6.25 \%)$ with $3^{\text {rd }}$-degree hypertension.

Table 4.2. Classification of Blood Pressure After Lavender Aromatherapy Administration

\begin{tabular}{|c|c|c|c|c|c|c|c|}
\hline \multirow[t]{2}{*}{ No } & \multirow[t]{2}{*}{ Blood Pressure Classification } & \multicolumn{2}{|c|}{ Treatment } & \multicolumn{2}{|c|}{ Control } & \multicolumn{2}{|r|}{ Total } \\
\hline & & $\mathrm{F}$ & $\%$ & $\mathrm{~F}$ & $\%$ & $\mathrm{~F}$ & $\%$ \\
\hline 1 & Optimal Blood Pressure & 0 & 0 & 0 & 0 & 0 & 0 \\
\hline 2 & Normal Blood Pressure & 1 & 6.25 & 0 & $-\quad 0$ & 1 & 3.125 \\
\hline 3 & High Normal Blood Pressure & 6 & 37.5 & 1 & 6.25 & 7 & 21.875 \\
\hline 4 & 1st-degree Hypertension & 5 & 31.25 & 5 & 31.25 & 10 & 31.25 \\
\hline 5 & $2^{\text {nd-degree Hypertension }}$ & 4 & 25 & 9 & 56.25 & 13 & 40.625 \\
\hline 6 & $3^{\text {rd-degree Hypertension }}$ & 0 & 0 & 1 & 6.25 & 1 & 3.125 \\
\hline 7 & Isolated Systolic Hypertension & 0 & - & 0 & 0 & 0 & $\begin{array}{l}-\quad 0 \\
\end{array}$ \\
\hline Total & & 16 & 100 & 16 & 100 & 32 & $-\quad 100$ \\
\hline
\end{tabular}

Table 4.2 shows the classification of blood pressure developed by respondents. Nearly a half of respondents developed hypertension in treatment group, including 6 respondents (62.5\%) with high normal blood pressure and $1(6.25 \%)$ with normal blood pressure. Meanwhile, most respondents in control group developed $2^{\text {nd }}$-degree hypertension, including 9 respondents $(56.25 \%)$ with high normal blood pressure and $1(6.25 \%)$ with $3^{\text {rd }-d e g r e e ~ h y p e r t e n s i o n . ~}$

Table 4.3. Distribution of Blood Pressure Classification related to the effect of Lavender Aromatherapy for $\mathbf{7}$ days in Treatment Group

\begin{tabular}{|c|c|c|c|c|c|c|c|}
\hline \multirow[t]{3}{*}{ No } & \multirow[t]{3}{*}{ - Type of Blood Pressure } & \multicolumn{6}{|c|}{- Treatment } \\
\hline & & & \multicolumn{2}{|r|}{ Pre Test } & \multirow{2}{*}{\multicolumn{2}{|c|}{$\begin{array}{c}- \\
-\quad F\end{array}$}} & Post Test \\
\hline & & & $-F$ & $-\quad \%$ & & & $-\quad \%$ \\
\hline 1 & Optimal Blood Pressure & & 0 & - & - & 0 & -0 \\
\hline 2 & Normal Blood Pressure & & 0 & - & - & 1 & -6.25 \\
\hline 3 & High Normal Blood Pressure & & 0 & $-\quad 0$ & - & 6 & $-\quad 37.5$ \\
\hline 4 & $1^{\text {st-degree Hypertension }}$ & - & 5 & - $\quad 31.25$ & - & 5 & $-\quad 31.25$ \\
\hline 5 & $2^{\text {nd }}$-degree Hypertension & & 10 & $-\quad 62.5$ & - & 4 & -25 \\
\hline 6 & $3^{\text {rd-degree Hypertension }}$ & - & 1 & $-\quad 6.25$ & - & 0 & - \\
\hline 7 & Isolated Systolic Hypertension & - & 0 & $-\quad 0$ & - & 0 & - \\
\hline Tota & & & 16 & -100 & & 16 & -100 \\
\hline
\end{tabular}

Table 4.3 shows the classification of blood pressure in relation to the effect of lavender aromatherapy administration experienced by the respondents in treatment group. Nearly a half of respondents ( 6 respondents or 37.5\%) have high normal blood pressure and only 1 $(6.25 \%)$ has normal blood pressure. 
Table 4.4. Distribution of Blood Pressure Classification related to the effect of Lavender Aromatherapy for 7 days in Control Group

\begin{tabular}{|c|c|c|c|c|c|c|c|c|}
\hline \multirow[t]{3}{*}{ No } & \multirow[t]{3}{*}{ - $\quad$ Type of Blood Pressure } & \multicolumn{7}{|c|}{ - Control } \\
\hline & & \multirow[b]{2}{*}{-} & - & \multicolumn{2}{|c|}{ Pre Test } & \multicolumn{2}{|r|}{-} & Post Test \\
\hline & & & $\mathrm{F}$ & - & $\%$ & - & $\mathrm{F}$ & $\%$ \\
\hline 1 & Optimal Blood Pressure & - & 0 & - & 0 & - & 0 & - \\
\hline 2 & Normal Blood Pressure & - & 0 & - & 0 & - & 0 & - \\
\hline 3 & High Normal Blood Pressure & - & 0 & - & 0 & - & 1 & $-\quad 6.25$ \\
\hline 4 & $1^{\text {st-degree Hypertension }}$ & - & 7 & - & 43.75 & - & 5 & 31.25 \\
\hline 5 & $2^{\text {nd-degree Hypertension }}$ & - & 8 & - & 50 & - & 9 & 56.25 \\
\hline 6 & $3^{\text {rd-degree Hypertension }}$ & - & 1 & - & 6.25 & - & 1 & $-\quad 6.25$ \\
\hline 7 & Isolated Systolic Hypertension & - & 0 & - & 0 & - & 0 & $-\quad 0$ \\
\hline Total & & & 16 & - & 100 & & 16 & 100 \\
\hline
\end{tabular}

Table 4.4 shows the classification of blood pressure developed by the respondents for 7 days in control group. Most respondents (9 or 56.25\%) developed $2^{\text {nd }}$-degree hypertension and 1 (6.25\%) has high normal blood pressure and 1 (6.25\%) has $3^{\text {rd }-d e g r e e ~ h y p e r t e n s i o n . ~}$

The result of normality test calculation in treatment group is distributed normally; therefore statistic test used was Paired T-test at significance level $p=0.008(p<\alpha=0.05)$, meaning that there is an effect of lavender aromatherapy on changing blood pressure in middle age with primary hypertension. In addition, the result of normality test calculation in control group is distributed normally; therefore statistic test used was Paired T-test at significance level $\mathrm{p}=$ $0.358(\mathrm{p}<\alpha=0.05)$, meaning that there is a significant effect of lavender aromatherapy on changing blood pressure in middle age with primary hypertension.

\section{DISCUSSION}

\section{Blood Pressure Before Lavender Aromatherapy Administration}

From the result of research on 32 respondents, it can be found that $100 \%$ respondents develop primary hypertension. Most respondents developing hypertension are in treatment group, including 10 respondents (62.5\%) with $2^{\text {nd }}$-degree hypertension and $1(6.25 \%)$ with $3^{\text {rd }}$ degree hypertension. Meanwhile, a half of respondents in control group develop hypertension, including 8 respondents (50\%) with $2^{\text {nd }}$-degree hypertension and $1(6.25 \%)$ with $3^{\text {rd }}$-degree hypertension. Their blood pressure is high with unknown cause, whether cardiovascular or lifestyle factor.

Primary hypertension is the increased blood pressure with unknown medical cause. The causes putatively contributing to the increased blood pressure are, among others: about 10\% of adult populations develop secondary hypertension, more than $90 \%$ of them develop essential (primary) hypertension without identified medical causes such as emotional disorder, obesity, excessive alcohol intake, and excessive stimulation with coffee, tobacco, and stimulating drugs contributing very considerably, very familial in nature, and attacking more women than men, but African-American men can tolerate this disease less adequately [1]. Age, sex, and genetic are uncontrollable factor. Meanwhile, obesity, less exercise, smoking, alcohol, and emotional stress are controllable risk factors [12]. Hypertensive case at less than 50-year age is found more in men than in women, as women have estrogen hormone that can prevent hypertension from occurring, but at 55- or 60-year age, hypertension is found more in women than in men.

From the research on the respondents, the author found that the factors causing the increase in blood pressure are: uncontrolled salty food consumption and majority respondents love fried food, innards, sate kambing (goat meat roasted on skewer), greasy food such as bakso, gulai, 
rawon, soto. Additionally, male respondents love drinking coffee accompanied with smoking and fried food while begadang (staying up and talking all night) so that their sleeping rest is reduced either quantitatively or qualitatively because at productive age, respondents have too many thing to think of (stress). The stress-related problems such as hypertension, headache, and insomnia can be reduced or healed with relaxation [18]. Recalling the lifestyle occurring, many alternative therapies for high blood pressure disease focus on relaxation technique and some others try to find the root of problem physiologically by means of changing their habit or lifestyle. One of relaxation therapies used in hypertension management is lavender aromatherapy.

\section{Blood Pressure after Lavender Aromatherapy Administration}

The result of research conducted on 16 respondents by administering relaxation therapy (lavender aromatherapy) shows the same response, namely, the respondents seem to be more relaxed, comfortable, and calm, and their dizziness is reduced. Nearly a half of (6 or 37.5\%) respondents in treatment group have high normal blood pressure and 1 respondent (6.25\%) has normal blood pressure. Meanwhile, in control group most ( 9 or $56.25 \%$ ) respondents have $2^{\text {nd }}$-degree hypertension and minority (1 or $6.25 \%$ ) respondents have high normal blood pressure respondents has $3^{\text {rd }}$-degree hypertension and $1(6.25 \%)$ has $3^{\text {rd }}$-degree hypertension.

The main chemical component of lavender oil is linoil acetic, linalool. Lavender aroma used through lavender inhaler can improve alpha waves in the brain and these waves help create relaxed situation improving sleep comfort, improving counting precision, and reducing agitation among patients with dementia [10]. It is in line with a previous study finding that inhaling aromatherapy will increase alpha wave in the brain and it is this wave that helps us relaxed; it can reduce vasoconstriction activity of blood vessel leading to the smooth blood circulation thereby reducing blood pressure [11]. Lavender can provide tranquility, balance, comfort, openness, and conviction. In addition, lavender can also reduce depression, stress, pain, imbalanced emotion, hysteria, frustration, and panic. Lavender can be useful to reduce pain and provide relaxation.

Linoil acetic or linalool content of lavender oil effectively decreases blood pressure, as indicated with the decreased blood pressure of respondents in treatment group. Relaxation (lavender aromatherapy) administration for \pm 10 minutes within 7 days and companied with low salt and fat diet as well as regular exercise can decrease blood pressure effectively.

\section{The Effect of Lavender Aromatherapy on Changing Blood Pressure}

The result of research shows that lavender aromatherapy administration affects blood pressure decrease significantly, with the result of Paired $T$ test obtaining significance value $p=0.008(\mathrm{p}<\alpha=0,05)$, meaning that there is an effect of lavender aromatherapy on changing blood pressure in middle age with primary hypertension.

The substance of linoil acetic linalool contained in lavender essential oil can result in relaxation by stimulating body tissue tactility leading to a complex neurohumoral response in The Hypothalamic-Pituitary Axis (HPA) to the circuit through nervous system channel. Stress adaptation is regulated by HPA capacity to secret such hormones as cortisol and endorphin reducing sympathetic nervous system activity and improving parasympathetic nervous response. Cortisol is the main stress hormone and end product of sympathetic nerve. Meanwhile, lavender essential oil works to stimulate olfactory nervous cell and affecting the function of limbic system by improving positive and relaxed feeling. During breathing, smell stimulation comes to sensory cells through air diffusion. Smell molecules are bond directly 
through olfactory receptor or to specific binding protein bringing the smell to the receptor and leading the nerves to turn on potential action. Entire events are delivered to limbic system responsible for emotion and brain registers it as the specific smell and then secretes serotonin resulting in the physiological change in body, mind, and mentality (soul) and resulting in sedating effect in the body [14]. Thus, heart function does not need strong pressure to pump and to circulate blood throughout body maximally.

Lavender aromatherapy administration by means of inhalation affects significantly the decrease of blood pressure; the combination of chemicals in lavender can stimulate olfactory nervous cell and affect the function of limbic system by improving positive and relaxed feelings; thus, heart function does not need strong pressure to pump and to circulate blood throughout body maximally, thereby having a very large potency to decrease and to maintain blood pressure. From the result of observation conducted by the author, it can be found that middle age with primary hypertension in treatment group reveals reduced headache and sleeping disorder complaint, and generally seems to be more relaxed. Thus, lavender aromatherapy administration is responded to positively by respondents as the fragrant aroma can be the option in controlling blood pressure without the feeling of being tortured during therapy. It proves that relaxation therapy (lavender aromatherapy) decreases blood pressure effectively among patients with primary hypertension.

\section{CONCLUSION}

1. Blood pressure of patients with primary hypertension in treatment group before lavender aromatherapy administration includes $2^{\text {nd }}$-degree hypertension (10 respondents or $62.5 \%$ ) and $3^{\text {rd }}$-degree hypertension ( 1 respondent or $6.25 \%$ ). Meanwhile, a half (8 or $50 \%$ ) of respondents in control group has $2^{\text {nd }}$-degree hypertension and $1(6.25 \%)$ respondent has $3^{\text {rd-degree hypertension. }}$

2. Blood pressure of patients with primary hypertension in treatment group after lavender aromatherapy administration includes high normal blood pressure in 6 respondents (37.5\%) and normal blood pressure in 1 respondent (6.25\%). Meanwhile, in control group it includes $2^{\text {nd }}$-degree hypertension in 9 respondents $(56.25 \%)$ and high normal blood pressure in 1 respondent (6.25\%), and $3^{\text {rd }}$-degree hypertension in 1 respondent $(6.25 \%)$.

3. There is an effect of lavender aromatherapy on changing blood pressure in middle age with primary hypertension $(p=0.008<\alpha=0.05)$.

\section{ACKNOWLEDGMENT}

The author would like to thank to Director of Dian Husada Nursing Academy for his support and motivation in this research.

\section{References}

Brunner dan Suddart. 2002. Buku Ajar Keperawatan Medikal Bedah. Jakarta: EGC

Depkes R.I., 2008. Profil Kesehatan Indonesia. Jakarta

Depkes RI. 2000. Survei Kesehatan Rumah Tangga (SKRT). Jakarta.

Dinkes Kota Mojokerto. 2011. DINKES Evaluasi JAMKESDA. http://mojokertokota.go.id/media.php/berita/details/nw201112301006464

Harvey, Richard A. \& Pamela C. Champe. (2013). Farmakologi ulasan bergambar. Jakarta : EGC Jaelani. 2009. Aromaterapi. Jakarta: Pustaka Populer Obor

Kemenkes RI. 2012. Buletin Penyakit Tidak Menular. Jakarta from

Kemenkes RI. 2013. Buletin Jendela Data dan Informasi Kesehatan www.depkes.go.id.

Kusnul, Z dan Zainal, M .2010. Efek Pemberian Jus Mentimun terhadap Penurunan Tekanan Darah. http://www.academia.edu/4717267/EFEK 
Maifrisco, 0. 2008. Pengaruh Aromaterapi Terhadap Tingkat Stress Mahasiswa. Available from URL; www.indoskripsi.com.

Majidi, Ahmad dan Juanita, Farida (2013).Pemberian Aromaterapi Kenanga (Cananga Odorata) Untuk Menurunkan Tekanan Darah Lansia Di Dusun Sumlaran Desa Sukodadi Kecamatan Sukodadi Kabupaten Lamongan. Vol.03, No.XVI, Desember 2013

Mansjoer, A.2000. Kapita Selekta Kedokteran Jilid 1. Jakarta: Media Aesculapius

Rahajeng E, Tuminah S. Prevalensi Hipertensi dan Determinannya di Indonesia. Jakarta: Pusat Penelitian Biomedis dan Farmasi Badan

Remington (2006): The Science and Practice of Pharmacy, 21 stm Ed., 916, Lippincott Williams and Wilkins, University of Sciences, Philadelphia.

Riseksdas 2013. Laporan Riset Kesehatan Dasar. www.litbang.depkes.go.id/sites/download/rkd2013/LaporanRiskesdas2013.PDF

Riskesdas 2007. Ringkasan Profile Kesehatan di Indonesia. http://selasi.net.index.php?optim=com.

Ritu, J. 2011. Pengobatan Alternatif untuk Mengatasi Tekanan Darah. Jakarta: Medika

Subandi. 2003. Psikoterapi, Pendekatan Konvensional dan Kontemporer. Yogyakarta: Pustaka Pelajar

Sukmono, R, J. 2009. Mengatasi Aneka Penyakit dengan Terapi Herbal. Jakarta: Argo Media Pustaka

Walsh, M. E., Debra, R., Tisha, J. 2011. Journal of Vascular Nursing. Integrating Complementary and Alternative Medicine: Use of Essentials Oils in Hypertension Management. Volume 29 No. 2

Wirakusumah, E. S., 2000. Buah dan Sayur untuk Terapi. Penebar Swadaya, Jakarta. 